\title{
Effect of the terroir and the harvest time on the Kékfrankos grape berries visual and physical parameters in Eger (Hungary)
}

\author{
Barócsi, Z. \\ Szent István University, Institute of Horticulture; H-2100 Gödöllö, Páter Károly 1., \\ Barocsi.Zoltan@mkk.szie.hu
}

\begin{abstract}
Summary: In this research, the effects of the "terroir" and the harvest time on the most important physical properties of the berries of Kékfrankos (Blaufrankish) grape variety were examined in 2010 and 2011. The results of the experimentation shown, that the maturation processes can be well described by different physical parameters of the grape berry. The terroir and harvest time effects were investigated in two different vintages and four different territories. It can be concluded, that these physical parameters change significantly during the ripening period, but trends differ between vintages and regions.
\end{abstract}

Keywords: grape berry, sensorial analysis, berry skin, pulp, seed, "terroir" effect, harvest timing

\section{Introduction}

In this experimentation, the territory and the harvest timing effects on the main physical properties of Vitis vinifera L. cv. Kékfrankos (the most common red grape in Hungary and in Eger wine district) were investigated.

Combee (1992): during the ripening process, the cell structure and chemical composition of the pulp, berry skin and seeds are significantly changing. Blouin and Guimberteau (2000) defined that the highest anthocyanin concentration of the berry skin and the smallest seed tannin ratio can be measured at the time of the phenolic ripeness stage. In the method of Rousseau-Delteil (2000) the visual examinations concern the colour and mechanical resistance of the berries, the separability of the berry skin from the pulp and the colour of the seeds. Segade et al (2008) demonstrated that simple texture parameters (grape skin hardness and thickness) account for phenolic maturity of berry skin. In their experimentation a significant regression was found between anthocyanin extractability, berry skin break force and thickness. Berry skin break force and energy were proved to be the most important factors for varietal characterization.

Rolle et al (2009) evaluated the extractability of anthocyanins from grapevines with different skin hardness and ripening stages. In their experimentation for each ripening stage, the harder skin had greater anthocyanin extractability. Significant interactions were found between ripening stage; skin hardness and anthocyanin composition as well.

Maury et al. (2009) developed a mechanical texture measurement method for the case of Cabernet franc grape berries. In the experimentations a discrimination of grapes coming from different parcels was demonstrated, moreover correlations were found between texture parameters and sensory descriptors. Authors propose their less costly texture analyzing method for monitoring the grape ripening process. Le Moigne et al. (2008) research concern about 30 different parameters of the yield Cabernet franc. A very close relationship were found between the sensorial character of the wine and the characteristics of the grape berries.

\section{Materials and methods}

\section{Experimental sites}

In our experiment, the following four different terroirs were compared in Eger wine district: Kölyuktető (1), Szomolya (2) Nagyeged-hill low (3) and topside (4). All parcels are described by north-south row lines. The applied training system was the umbrella pruned with two long canes. The examined red grape variety was the Vitis vinifera cv. Kékfrankos (Blaufrankish), grefted on Berlandieri x Riparia T.5.C root-stock.

\section{Vintages (Figures 1a, 1b, 1c)}

Both vintages $(2010,2011)$ showed extreme values compared to the average of many years. In 2010, the monthly average temperature values - except for July - remained below the long term average, while in 2011 the opposite trend was observed. Although the number of sunshine hours was favourable both years, in 2011 an outstanding value (2356 
hours) was observed. The biggest difference between the two years was found in the precipitation. In 2010 a significantly greater amount of precipitation has emerged than in previous years, however in the extremely dry 2011 only $390 \mathrm{~mm}$ of rain fell during the whole season.

\section{Figure $1(a, b, c)$ : Meteorological datas in 2010 and 2011 compared with the 49 previous years averages (Eger-Kölyuktetö)}

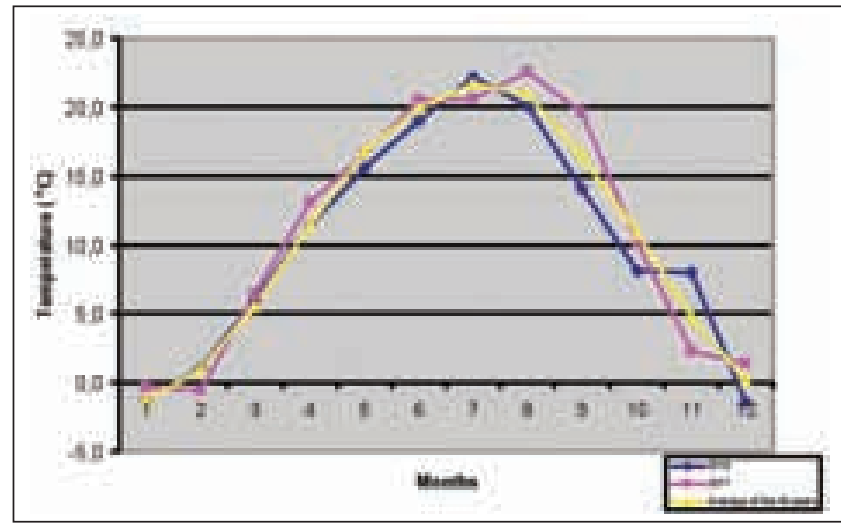

Figure 1a: Monthly average temperatures in 2010 and in 2011, compared with the average of 49 previous years

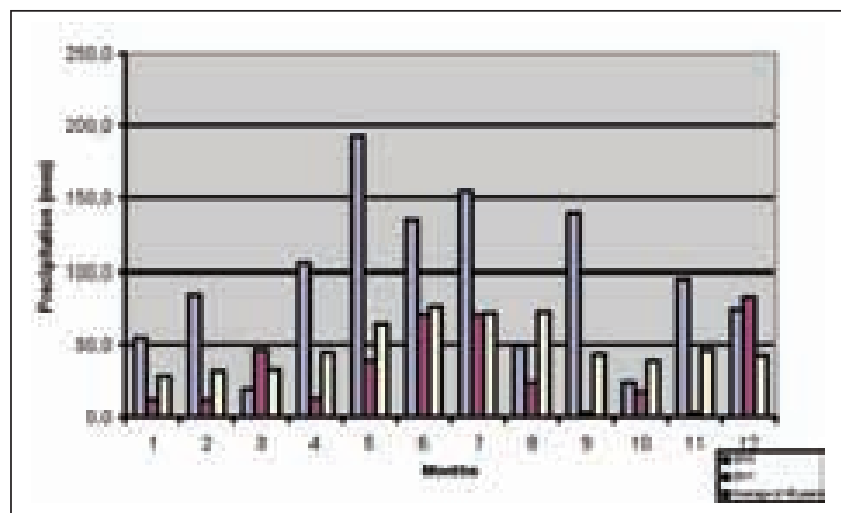

Figure 1b: Monthly precipitations in 2010 and in 2011, compared with the average of 49 previous years

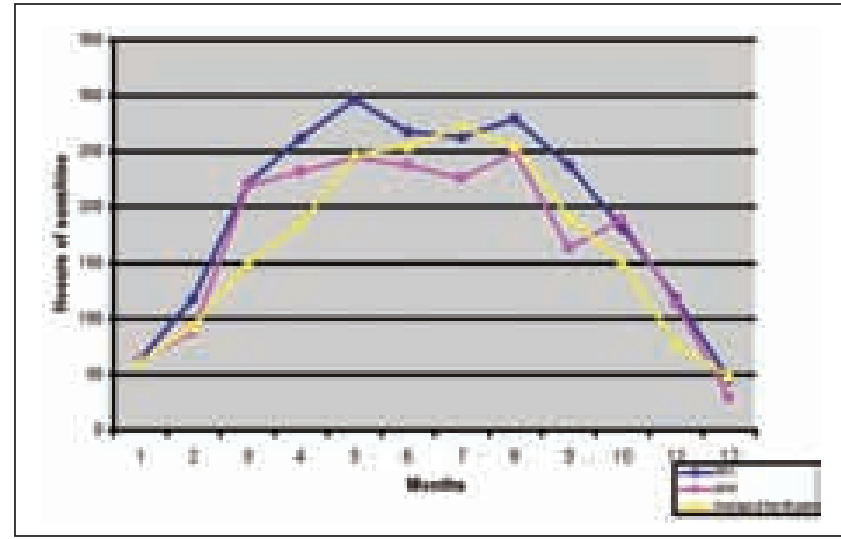

Figure 1c: Monthly insolation hours in 2010 and in 2011, compared with the average of 49 previous years

\section{Samplings}

We collected a simple of 300 berries from the different spots of plantations, from the two sides of the canopy walls, from the different bunch levels of the shoots and from the different cluster zones. These representative samplings were directly analysed after delivery. During the experiment, four times from each parcels (five times in 2011) samples were collected according to the following dates presented in the table 1.

Table 1: Dates of the samplings (harvests) in both examined years

\begin{tabular}{|l|l|l|}
\hline & \multicolumn{1}{|c|}{2010} & \multicolumn{1}{c|}{2011} \\
\hline 1. First harvest & $26^{\text {th }}$ of september & $16^{\text {th }}$ of september \\
\hline 2. Second harvest & $5^{\text {th }}$ of october & $22^{\text {nd }}$ of september \\
\hline 3. Third harvest & $15^{\text {th }}$ of october & $3^{\text {rd }}$ of october \\
\hline 4. 4th harvest & $25^{\text {th }}$ of october 25 & $14^{\text {th }}$ of October \\
\hline 5. 5th harvest & - & $24^{\text {th }}$ of October \\
\hline
\end{tabular}

\section{Determination and evaluation of examined parameters}

The visual properties of the berry skin coloration was evaluated on a five-point scale (range between pale red and blue-black), after removal of their wax layer. A previously developed colour scale was used for the evaluation of the berry skin coloration (Figure 2.).

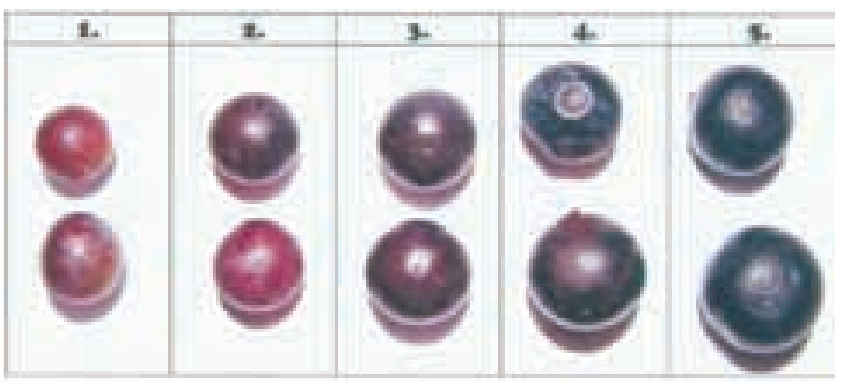

Figure 2: Scale used in the evaluation of the berry skin

The seed colour intensities were rated on a five-point scale, from the completely green to the completely brown tinctures.

As a physical parameter, the hardness of the berries was determined by their compression and was quantified on a five-point scale. The smallest values mean the hardest berry skin, so parallel to the berry softening, highest scores were given. The value of five means a shrivelled berry. During the compression of the berries, the separability of the berries was examined as well, between the two extreme categories: non separable and easily disrupted by touch. We evaluated the juiciness of the berries on a five-point scale, between two extreme categories: poor in juice and very juicy. The hardness of the seed was evaluated after their chewing and we quantified this character on a five-point scale, between the completely soft and fully hard, "crunchy" categories. The sensorial analyses were organised in the KRF Research 
Institute for Viticulture and Oenology, Eger. From the collected samples, 20 berries were taken randomly by 6 tasters, so all samples were analysed in 120 repetitions by each evaluators. The collected samples was carried out from 20 to 20 berries were taken at random, so every batch of 120 replicates were evaluated, from 1 to 5 integers. The evaluation form is shown in the table 2 .

Table 2: Evaluation form for berry sensorial analyses

\begin{tabular}{|c|c|c|c|c|c|c|c|}
\hline \multicolumn{7}{|c|}{ BERRY SKIN } \\
\hline $\begin{array}{c}\text { Berry } \\
\text { number } \\
(1-20)\end{array}$ & $\begin{array}{c}\text { Intensity of } \\
\text { the colour } \\
\text { (blue/red) }\end{array}$ & Hardness & $\begin{array}{c}\text { Separability } \\
\text { pulp/skin }\end{array}$ & $\begin{array}{c}\text { Tannin } \\
\text { flavour } \\
\text { intensity }\end{array}$ & Astringency & $\begin{array}{c}\text { Vegetal } \\
\text { character }\end{array}$ & $\begin{array}{c}\text { Fruity } \\
\text { character }\end{array}$ \\
\hline $\begin{array}{c}\text { Berry } \\
\text { number } \\
(1-20)\end{array}$ & $\begin{array}{c}\text { Sugar } \\
\text { intensity }\end{array}$ & Acidity & $\begin{array}{c}\text { Bcid composi- } \\
\text { tion }\end{array}$ & $\begin{array}{c}\text { Vegetal } \\
\text { flavour }\end{array}$ & Fruity aromas & $\begin{array}{c}\text { Spicy } \\
\text { aromas }\end{array}$ & Juiciness \\
\hline $\begin{array}{c}\text { Berry } \\
\text { number } \\
(1-20)\end{array}$ & $\begin{array}{c}\text { Colour } \\
\text { intensity } \\
\text { (brown) }\end{array}$ & HEEDS & Ardness & Tannin-intensity & Astringency \\
\hline
\end{tabular}

small differences were found in this parameter. In 2010, in spite of the bad vintage effect, the terroir and the harvest time both influenced significantly the berry coloration. The date of harvest was later, the berry skin became deeper in colour. Among the four examined terroirs, the Nagyeged parcels showed the fastest colour accumulation. In 2011, the Nagyeged-top reached first the maximum berry coloration.

The differences (areas or harvest dates) in seed coloration proved to be more significant compared to the berry coloration. In 2010, by the postponing of the harvest time, the brownish color of the seeds increased significantly. The slight differences formed between the different terroirs, can partly explained by the heterogeneous maturation of the berries. In 2011, in the case of the Nagyeged hilllow parcel, the brown coloration of the seeds was changed nearly linearly during ripening. Larger fluctuations were found in the data of the other terroirs.
For the statistical data processing and for the computer graphic evaluation of the obtained average values the Microsoft Excel and SPSS software's were used. First, we verified the homogeneity of the berries used as a sample by the Kruskal-Wallis test, than we examined by the Friedman's rank analysis tests, whether statistically significant differences could be verified between the different terroirs or in the same areas between the different harvest times.

\section{Results and discussions}

\section{Visual properties of berries (Figures $3 a, b, c, d, e$ )}

In relation to the berry skin coloration, we determined that both years the anthocyanin accumulation was very fast, because already at the first harvest time a darkish blue colour was observed. Later, during the ripening period only

\section{Physical properties of the grapes (Figures $3 a, b, c, d, e$ )}

In parallel of the harvest time postponing, the hardness of the berries both vintages was equally decreased. In 2010, particularly at the last sampling time there was a significant change in this respect, while in 2011 the berries reached their typical soft consistency already to the second harvest time. The differences between the regions were not clear.

The separability of the berry skin from the pulp was gradually improved during the course of maturation in 2010 , while in 2011 only minor differences were observed. In 2010, among the experimental regions, only the Nagy-Eged hill (upper and lower) showed a mild increase of this parameter, however significant differences characterized each parcels in 2011.

While the berries were softening, an increasing juiciness was occurred in 2010, for each parcels. In the case of the Nagyeged parcels, a more concentrated and occasionally

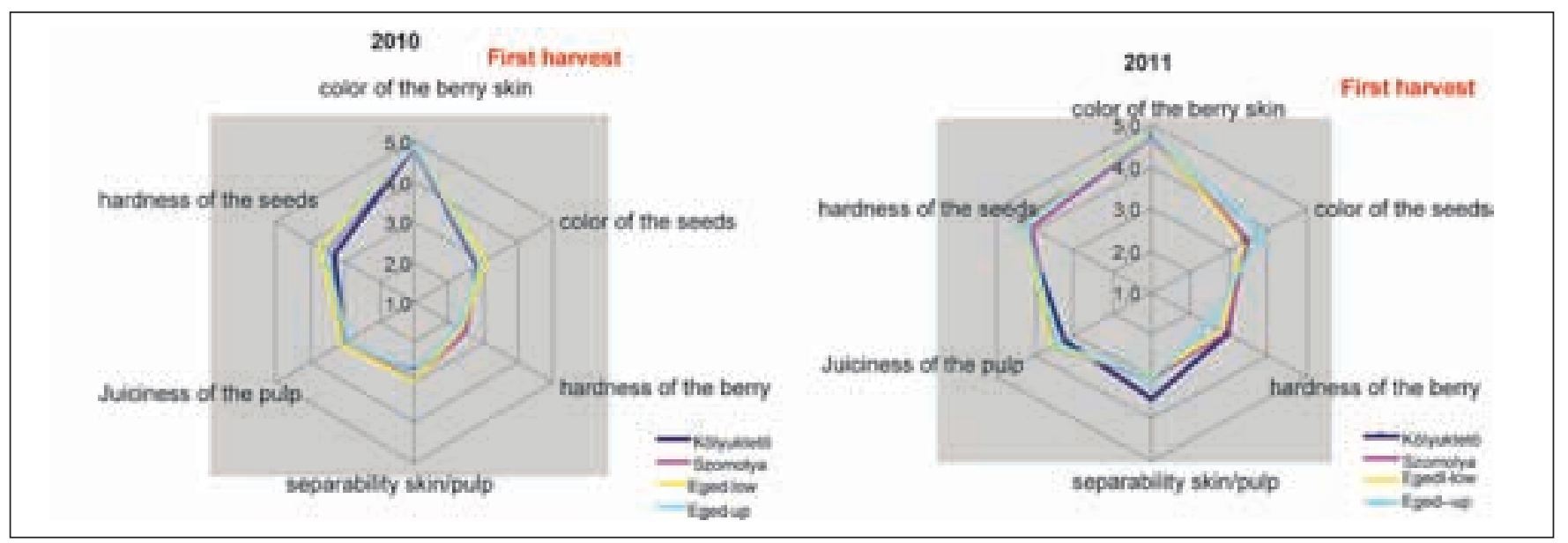

Figure 3 a: Main physical parameters of the berry (2010-2011-First harvest time) 
shrivelled berries were harvested at the end of October. Due to this fact, it can be stated, that these parcels have a big potential in the production of an outstanding quality red wine.

In 2011, the juiciness increased only slightly during ripening, and at the and of the season it started to decrease due to phenomenon of berry shrivelling. Statistically confirmed significant differences emerged between the observed terroirs in the first half of the harvest period.

Seed hardness showed a significant evolution in 2010 in all parcel simples, as the seeds lignified and became harder. In 2011, this parameter changed only slightly during the ripening process, but in the case of the Nagy-Eged samples

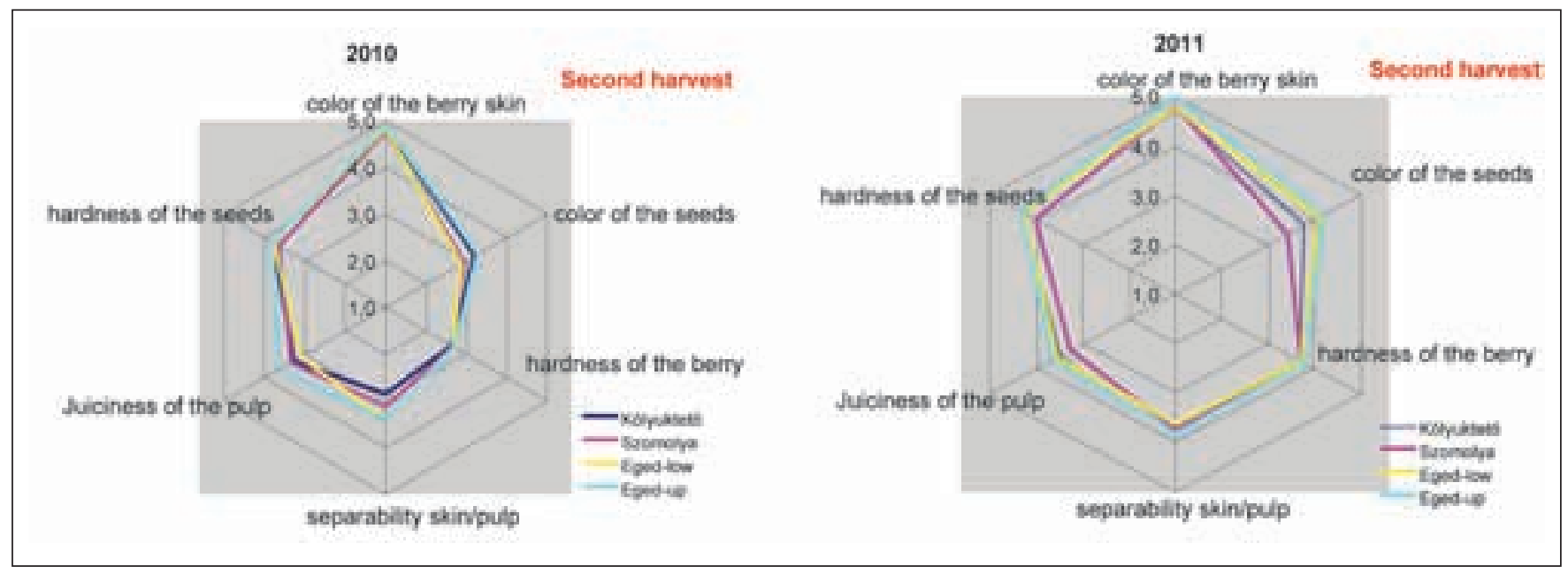

Figure 3 b: Main physical parameters of the berry (2010-2011-Second harvest time)

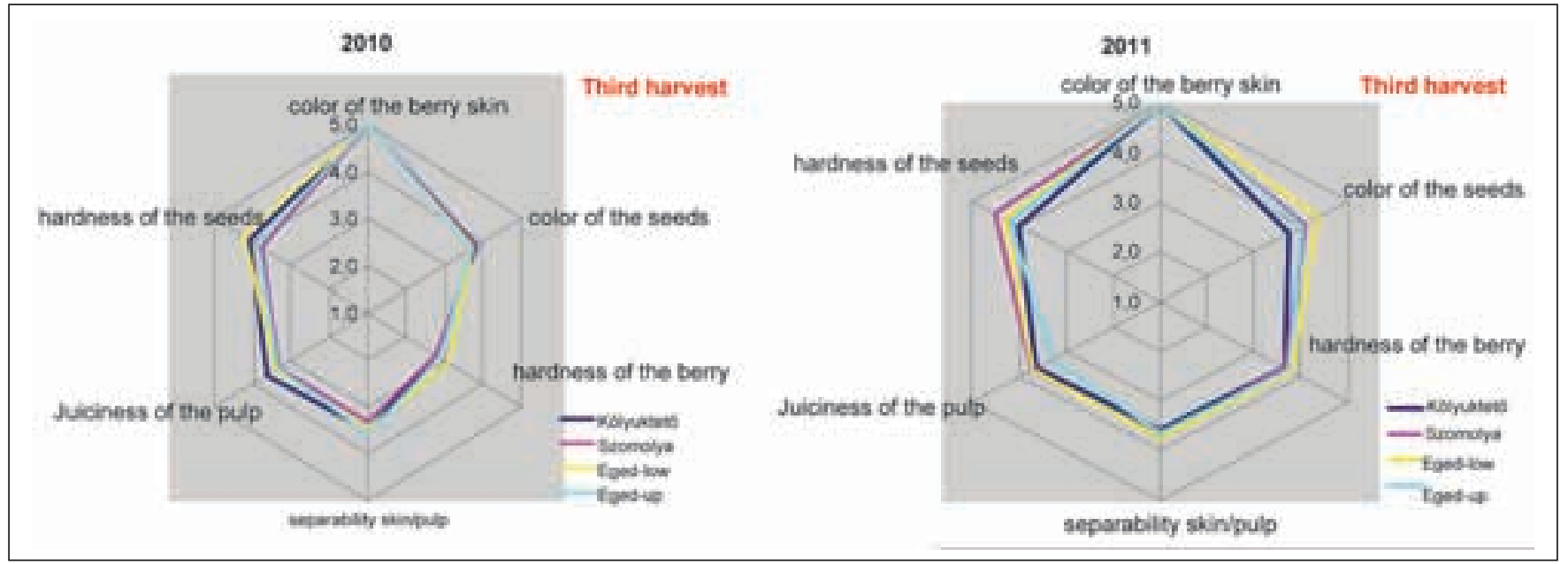

Figure 3 c: Main physical parameters of the berry (2010-2011-Third harvest time)

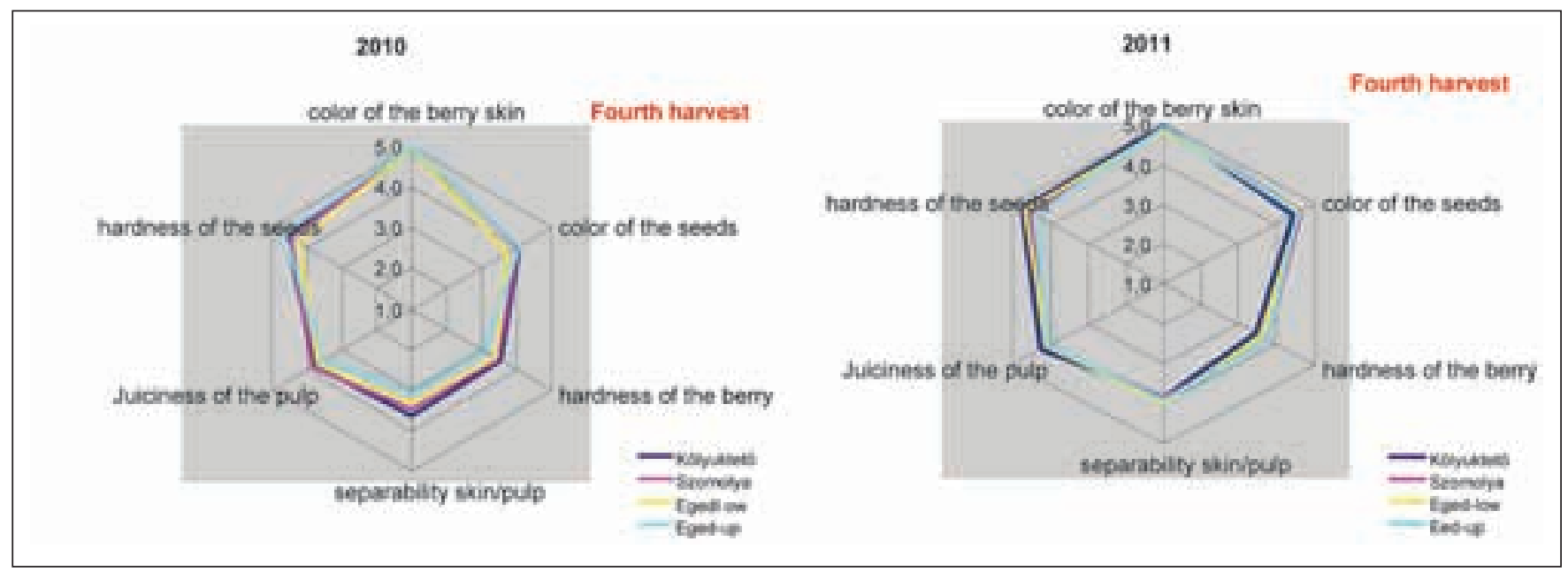

Figure 3 d: Main physical parameters of the berry (2010-2011-Fourth harvest time) 
showed high value already at the first sampling time. In contrast, the seed ripening process of the other parcels accelerated only by the end of harvesting season.

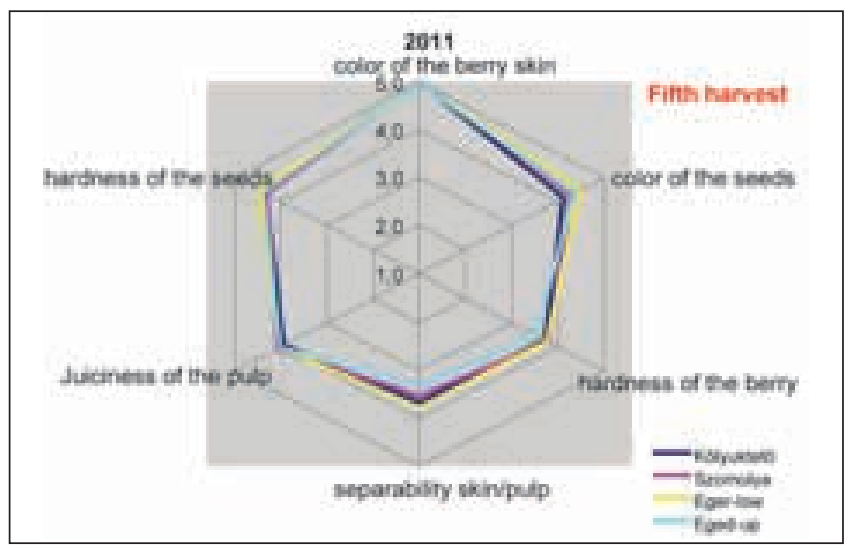

Figure $3 \boldsymbol{e}$ : Main physical parameters of the berry (2011-Fifth harvest time)

\section{Conclusions}

Concerning to the berry skin coloration, we observed no significant differences, because even the first sampling date was already characterized by a very high anthocyanin content. Visually it is not really evident to distinguish the different colour shades, if the antocyanin concentration is so high.

The seed coloration was strongly influenced by the territory and harvest time as well, both years. The berries became increasingly softer, and their juiciness increased till the phenological phase of over ripening. The separability of the berry skin from the pulp is significantly influenced by the vintages. In 2011 the berry skins were more adherent due to the drought effect. The hardness of the seeds increased significantly in 2010, while 2011 was characterized just by a slight change.
The berry sensorial analyses can effectively complete the monitoring of ripening season. These observed data of the different physical parameters of the berries, can be used in the practice of harvest time determinations.

\section{Acknowledgement}

The project was partly supported by ,az Emberi Erőforrások Minisztériuma által biztosított Kutató Kari Kiválósági Támogatás - Research Centre of Excellence 8526-5/2014/TUDPOL".

\section{References}

Blouin, J. \& Guimberteau, G. (2000): Maturation et maturité des raisins. Editeur Féret, Bordeaux, France

Coombe, B. G. (1992): Research on development and ripening of the grape berry. American Journal of Enology and Viticulture, 43: $11-110$.

Le Moigne, M., Maury, C., Bertrand, D. \& Jourjon, F. (2008): Sensory and instrumental characterisation of Cabernet Franc grapes according to ripening stages and growing location. Food and quality preference, 19.: 220-231.

Maury, C., Madieta, E., Le Moigne, M., Mehinagic, E. Siret, R. \& Jourjon, F (2009): Development of a mechanical texture test to evaluate the ripening process of cabernet franc grapes. Journal of Texture Studies, 5: 511-535.

Rolle, L., Torchio, F., Zeppa, G. \& Gerbi, V. (2009): Relationship between skin break force and anthocyanin extractability at different ripening stages. American Journal of Enology and Viticulture, 1: 93-97.

Rousseau J. \& Delteil, D. (2000): Evaluer la maturité en dégustant le raisin, Guide de la vinification rhodanienne; 4: 23-24. p.

Segade, R. S., Rolle, L., Gerbi, V. \& Orriols, I.: (2008): Phenolic ripeness assessment of grape skin by texture analysis. Journal of Food Composition and Analysis, 8: 644-649. 